Archive for

Organic Chemistry

Arkivoc 2020, part vii, 338-352

\title{
Preparation of benzannulated spiroketals by gold(III) catalyzed spirocyclization of alkynyl diols
}

\author{
Helgi Freyr Jónsson and Anne Fiksdahl* \\ Department of Chemistry, Norwegian University of Science and Technology \\ Høgskoleringen 5, 7491, Trondheim, Norway \\ Email: Anne.Fiksdahl@ntnu.no
}

Dedicated to Professor Jan Bergman on the occasion of his 80th birthday

Received 09-09-2020

Accepted $12-22-2020$

Published on line $01-04-2021$

\section{Abstract}

The first gold(III)-oxazoline catalysed intramolecular tandem dihydroalkoxylations of alkynyl diols to give benzannulated 5,6-spiroketal products is reported. The results showed that Au(III)-bisoxazoline (BOX) and $\mathrm{Au}(\mathrm{III})$-pyridine-oxazoline complexes are highly efficient catalysts for such spirocyclizations. The mono- and dibenzannulated 5,6-spiroketals were obtained in high yields ( $>90 \%$ ) by rapid conversion of symmetrical and nonsymmetrical alkynyl diols, respectively. The $\mathrm{Au}(\mathrm{III})-\mathrm{BOX}_{-} \mathrm{BF}_{4}$ catalyst generated minor spirocyclization enantioselectivity (up to $6 \%$ ee). The choice of solvent was important for the outcome of the reactions.

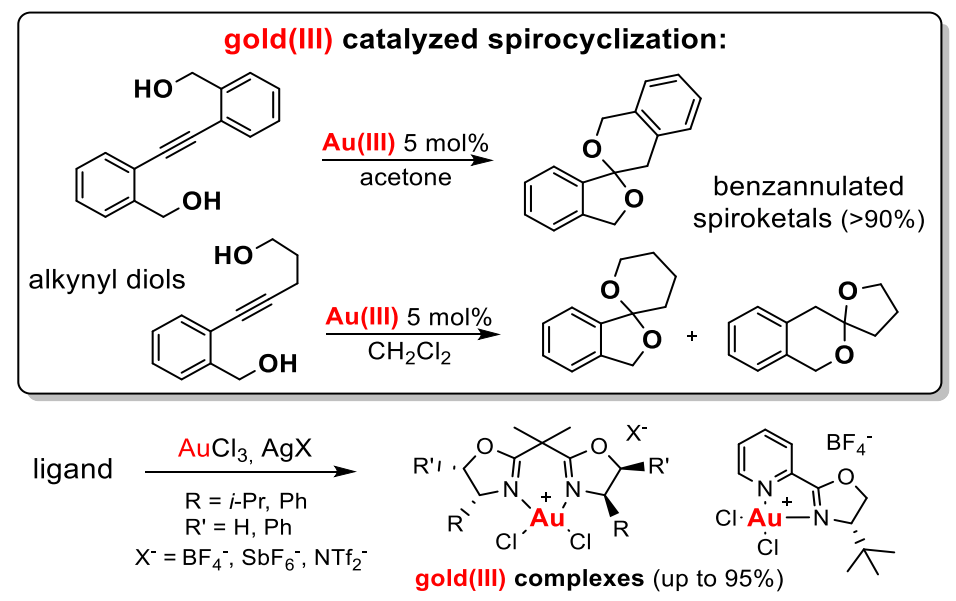

Keywords: spirocyclization; alkynyl diols; gold(III) catalysis; gold(III)-BOX complexes 


\section{Introduction}

Spiroketals are cyclic ketals in which two rings are joined via two ketal oxygens to a quaternary carbon, the spirocentre. The chiral spiroketal ring system is a structural motif found in a wide variety of densely functionalised natural products which exhibit a broad spectrum of biological activity. Examples of 5,5-, 5,6and 6,6-spiroketals include okadaic acid $(\mathbf{1})^{1,2}$, cephalostatin $1(\mathbf{2})^{3,4}$ and spongistatin $1(\mathbf{3})^{3,5}$ (Scheme 1 ), which have all shown cytotoxic activity, as well as rutamycin which also displays antifungal behaviour. ${ }^{6}$ The presence of the particular spiroketal fragment was correlated to increased inhibition of human telomerase by the rubromycin family of natural products. The specific chemistry of chiral benzannulated spiroketals has received much attention because they are common key substructures in bioactive natural products ${ }^{7}$ such as ? rubromycin (4), a 5,6-spiroketal comprised of an oxygenated naphthoquinone moiety linked with an isocoumarin fragment.

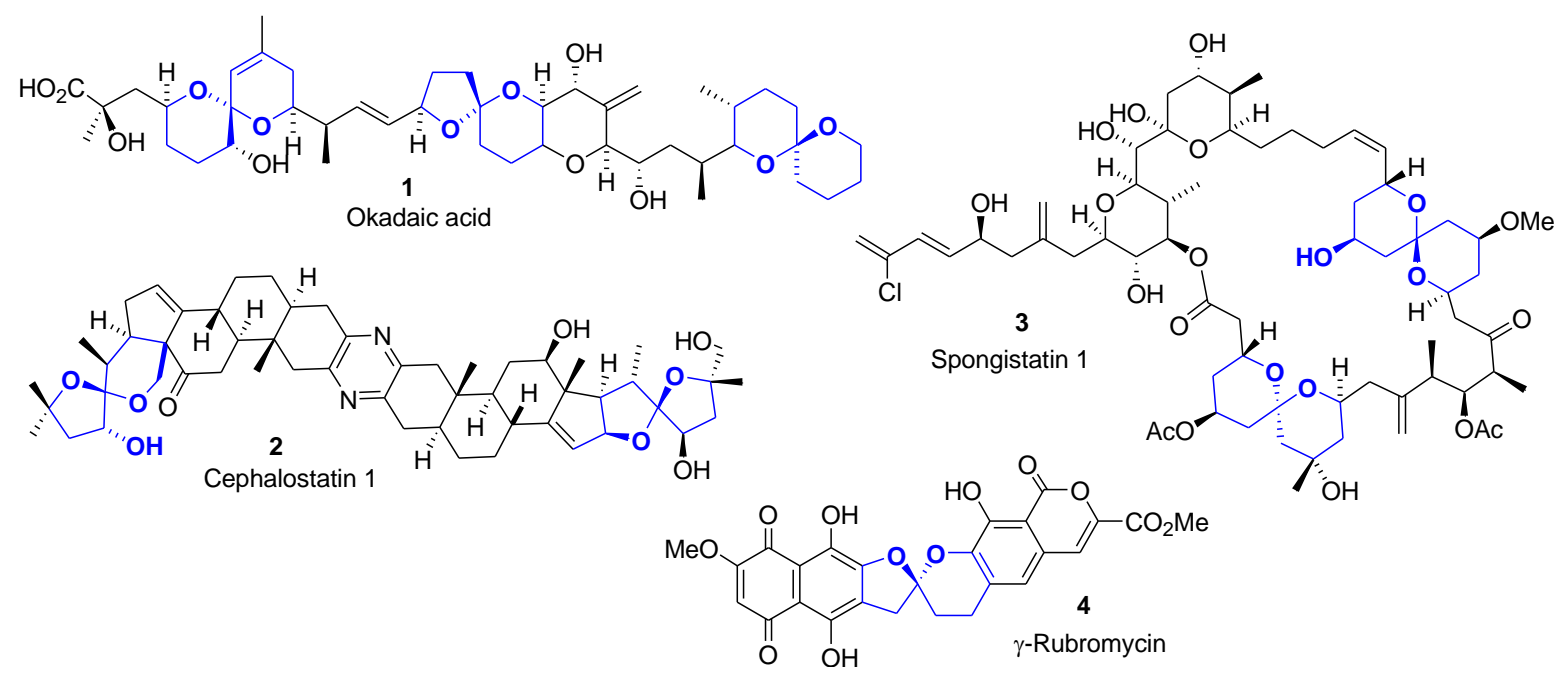

Scheme 1. Bioactive natural products containing spiroketal fragments.

The synthesis of spiroketals has received considerable attention. Most progress has been made on systems that include at least one six-membered ring. The synthesis of spiroketals has often been achieved by acid-catalysed condensation of either free or masked hydroxyfunctionalities on a ketone or other carbonyl surrogates. ${ }^{6,8-10}$ However, this poses some challenges due to the reactive nature of the carbonyl group. Lately, a cycloisomerization approach by intramolecular dihydroalkoxylation of alkynyl diols catalysed by various transition metals such as $\mathrm{Pd}(\mathrm{II}), \mathrm{Pt}(\mathrm{II}), \operatorname{Ir}(\mathrm{I}), \mathrm{Rh}(\mathrm{I}), \mathrm{Ru}(\mathrm{II})$ and $\mathrm{Au}(\mathrm{I} / \mathrm{III})$ has emerged as a more selective strategy. ${ }^{11-14}$ This method offers specific advantages, as the alkyne acts as a masked carbonyl group, and the non-polar alkyne $\pi$-bonds being more compatible than ketones towards a number of common reaction conditions. ${ }^{15}$

Gold catalysis has been a rapidly emerging field within transition metal catalysis in the past decade. Gold has a high affinity towards carbon-carbon multiple bonds, especially alkynes, which may be activated towards nucleophilic attack. The combination of high functional group tolerance and usually mild reaction conditions, allow a great diversity of gold catalysed transformations, also including enantioselective reactions. ${ }^{16}$ Due to these advantages, gold has been widely used for the synthesis of spiroketal natural products by intramolecular dihydroalkoxylation of alkynyl diols. ${ }^{4,17-20}$ This transformation has been achieved by simple gold 
salts such as $\mathrm{AuCl}^{19-21}$ and $\mathrm{AuCl}_{3}{ }^{12}$, as well as $\mathrm{Au}(\mathrm{I})$ phosphine complexes ${ }^{4,12,22}$, a $\mathrm{Au}(\mathrm{I}) \mathrm{NAC}$ complex ${ }^{23}$ and $\mathrm{Au}(\mathrm{I} / \mathrm{III}) \mathrm{NHC}$ complexes. ${ }^{24}$

As most naturally occurring spiroketals are chiral molecules with a stereogenic spirocentre, the syntheses of chiral spiroketals has attracted attention, targeting at high yields and high diastereo- and enantioselectivities under mild conditions. It is essential to avoid epimerization of the sterogenic spirocentre, which may easily take place under mild acidic conditions. 5,6- and 6,6-Spiroketals generally equilibrate toward a particular diastereoisomer under acidic conditions, due to anomeric or substituent stabilization in the sixmembered rings. ${ }^{25}$ Despite the fact that several approaches have been developed for spiroketal synthesis, methods for direct catalytic enantioselective synthesis of chiral spiroketals by transition-metal catalysis or organocatalysis are still limited. ${ }^{26-32}$ Highly enantioselective condensation reactions of unsaturated ketones to afford spiroketals (>99\% ee) have been performed with $\operatorname{Ir}(I)$ complexes of chiral phosphine-oxazoline ligands ${ }^{29}$, while catalytic enantioselective spiroketalizations by single $\mathrm{OH}$ attack on cyclic enol substrates ${ }^{27}$ are reported with both BINOL-derived chiral phosphoric acids $\left(\begin{array}{llll}92 & \% & \text { ee }\end{array}\right)^{26}$ and chiral BINOL-based imidodiphosphoric acid (>99\% ee). ${ }^{32}$ Benzannulated spiroacetals are successfully formed by intramolecular tandem dihydroalkoxylation of alkynyl diols by binary systems of both gold(I) complexes with chiral Brønsted acids (up to $93 \%$ ee) ${ }^{30}$ and chiral gold(I)-phosphine complexes with chiral silver phosphate (74 \% ee). ${ }^{31}$

In contrast to general broad studies based on gold(I) species, comprehensive studies of gold(III) are scarce. Thus, the limited experience of the chemistry of Au(III)-ligand species has inspired us to study the formation of new stable $\mathrm{Au}$ (III) complexes with a series of polydentate heterocyclic ligands. We have previously prepared and demonstrated the catalytic activity of Au(III) bisoxazoline (BOX) as well as Au(III) pyridyl/quinolinyl-oxazoline complexes in the cyclopropanation of propargyl acetates followed by cis-to-trans cyclopropyl isomerisation. ${ }^{33,34}$ Furthermore, pyridyl-oxazoline (PYR-OX) Au(III) complexes are also catalytically active in the alkoxycyclisation reaction of 1,6-enynes. ${ }^{35}$ Herein we report the first known study on spiroketalization based on Au(III)-BOX and -PYR-OX catalysed tandem dihydroalkoxylation of alkynyl diols to give benzannulated 5,6-spiroketal products. Regio- and stereoselectivity issues are included in the study.

\section{Results and Discussion}

\section{Preparation of aromatic alkynyl diols and chiral Au(III)-BOX complexes}

The symmetrically substituted diarylalkynyl diol 7 was obtained by Sonogashira cross-coupling of (2iodophenyl)methanol 4 with alkynaldehyde 5 via aldehyde 6 (75\%) and reduction (7, $57 \%)$, while the nonsymmetrical monoaromatic alkyne diol 9 (91\%) was readily obtained by cross-coupling of substrate 4 and alkynol 8 (Scheme 2). 


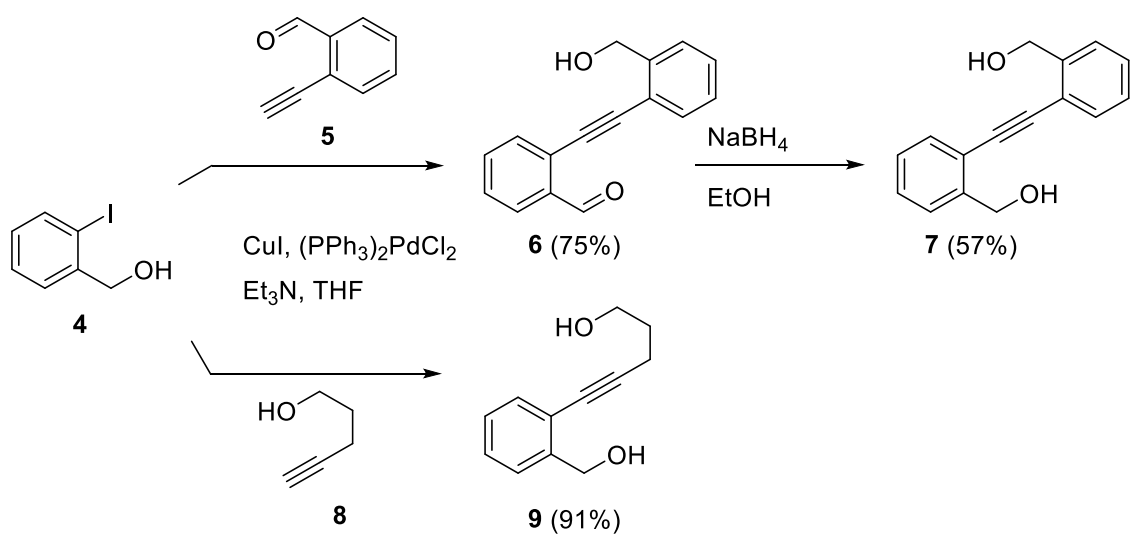

Scheme 2. Synthesis of alkynyl diols 7 and 9 by Sonogashira cross-coupling.

Chiral N,N-Au(III)-BOX and -PYR-OX ligand complexes were prepared according to our previous method $^{33}$ (Scheme 3). The respective heterocyclic bidentate BOX ligands 10a-10c and PYR-OX ligand 12 were dissolved in $\mathrm{CH}_{3} \mathrm{CN}$ before addition of $\mathrm{AuCl}_{3}$ and the appropriate silver salts. Crystallization yielded $\mathrm{Au}$ (III) $\mathrm{BOX}$ complexes 11a-e (47-95\%) and PYR-OX complex 13 (79\%) as air- and moisture stable crystals.
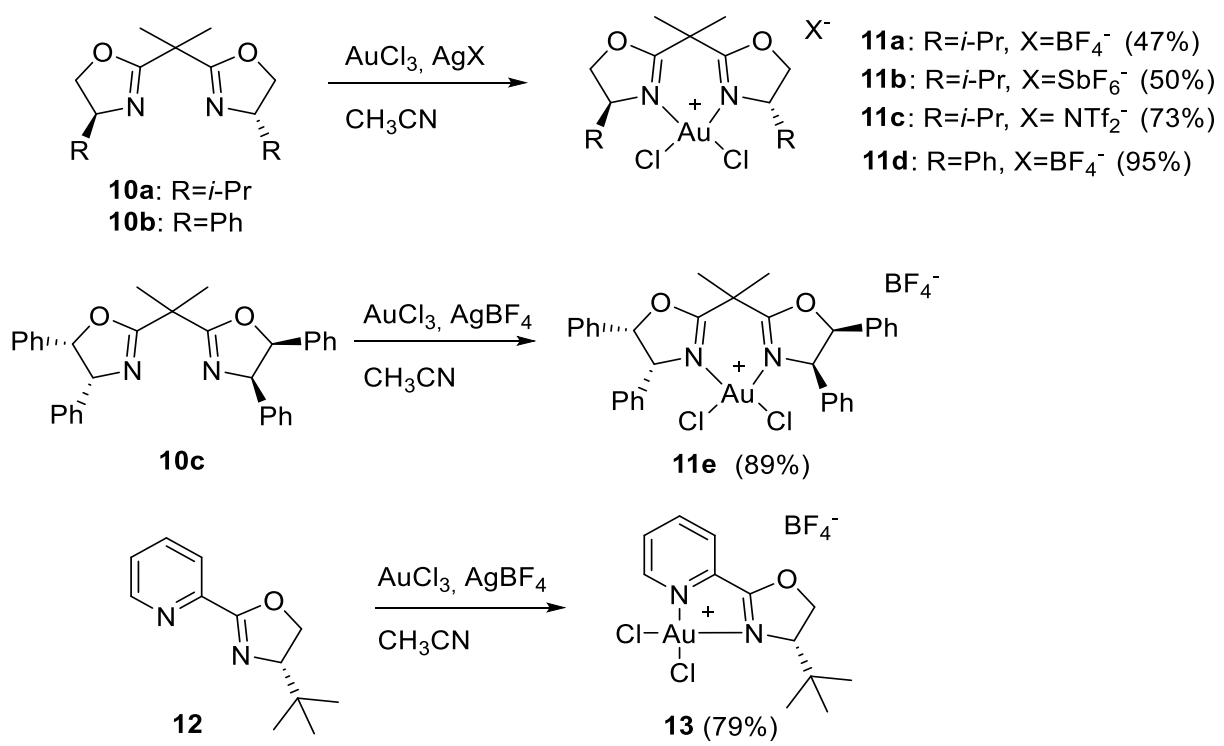

Scheme 3. Preparation of Au(III)-BOX complexes 11a-e and Au(III)-PYR-OX complex 13.

\section{Formation of benzannulated spiroketals by Au(III) catalysed dihydroalkoxylation of alkynyl diols}

1. Symmetrical alkyne substrate. With both substrates $(7,9)$ and gold(III) catalysts 11 a-e, 13 in hand, the reaction conditions for the dihydroalkoxylation reaction were screened. The symmetrical alkynyl diol $\mathbf{7}$ was treated with gold(III) complexes 11a-e and $\mathbf{1 3}$ (Scheme 3 ) in various solvents at room temperature to give the expected dibenzannulated 5,6-spiroketal 14 (spiro[isobenzofuran-1,3'-isochromane, Table 1). ${ }^{13}$

Initial solvent screening with catalyst $\mathrm{Au}(\mathrm{III})-\mathrm{BOX}_{-\mathrm{BF}_{4}}$ 11a showed that the reaction of alkynyl diol 7 may take place in several solvents $\left(\mathrm{CH}_{2} \mathrm{Cl}_{2}, \mathrm{CH}_{3} \mathrm{CN}\right.$, THF, toluene, $\mathrm{CH}_{3} \mathrm{NO}_{2}$, acetone) to give moderate to high yields of spiroketal product 14 (55-87 \%, 1-24 $\mathrm{h}$, entries 1-6). Most successful reaction by rapid conversion to spiroketal 14 in high yield was obtained in $\mathrm{CH}_{2} \mathrm{Cl}_{2}$ (84 \%, 1h, entry 1). Other solvents gave slower reaction (3-24 h, entries 2-6). 
Most reactions afforded racemic mixtures of spiroketal 14. Minor enantioselectivity and high yields were only provided in acetone ( $5 \%$ ee, $78 \%, 5 \mathrm{~h}$, entry 6). Despite the faster reactions and higher yields obtained in $\mathrm{CH}_{2} \mathrm{Cl}_{2}$ and $\mathrm{CH}_{3} \mathrm{NO}_{2}$ (84-87\%, 1-3h, entries 1,5), acetone was chosen as the solvent in further experiments with the other complexes, in order to achieve possibly higher \%ee values. However, nearly no enantioselectivity effect was seen with catalysts $\mathbf{1 1 b}$-e and $\mathbf{1 3}$ (0-3\% ee, entries 9-13).

Addition of a silver salt with a weakly coordinating anion is often necessary in gold catalysed reactions to abstract one or more gold bound chlorides, thus generating the catalytically active species. ${ }^{36,37}$ The Au(III) BOX complexes have been shown to be highly active without silver salt anion exchange, presumably due to decoordination of an oxazoline or pyridine moiety. ${ }^{33}$ However, the addition of $10 \mathrm{~mol}^{\circ} \mathrm{AgBF}_{4}$ accelerated the reaction with complex $11 \mathrm{a}$ and gave increased yield, but no ee ( $86 \%, 2 \mathrm{~h}$, entry 7$)$. The formation of a black solution immediately after silver salt addition indicated decomposition of the gold catalyst and that the reaction, in this case, might be gold(0) catalysed. As gold catalysed dihydroalkoxylation of alkynyl diols with chiral phosphoric acid co-catalysts has been successful ${ }^{30,38,39}$, a reaction with 10 mol\% S-camphorsulfonic acid was performed. The addition of acid sped up the reaction up significantly and gave excellent yield of product 14, but did not afford stereoselectivity (93\%, 1h, entry 8$)$.

The effect of different $\mathrm{Au}(\mathrm{III})$ counter-anions was then explored, but catalysts $\mathbf{1 1 b}, \mathbf{c}$ with $\mathrm{SbF}_{6}{ }^{-}$and $\mathrm{NTf}_{2}{ }^{-}$ anions, repectively, were less effective than $\mathrm{Au}(\mathrm{III})-\mathrm{BOX}-\mathrm{BF}_{4} 11 \mathrm{a}$ with regards to yields $(42-58 \%, 4-5 \mathrm{~h}, 2-3 \%$ ee, entries 9-10). However, both modified catalysts 11d,e, with the 4-phenyl-BOX and the bulkier 4,5-diphenylBOX ligands, were more active ( $86 \%$ and $70 \%, 2 \mathrm{~h}$, entries 11,12 ). The PYR-OX catalyst 13 turned out to be most active, giving almost immediate full conversion to product 14 (89\%, 30 min, 2 \%ee, entry 13). However, a black precipitate was formed almost directly after addition of catalyst $\mathbf{1 3}$, indicating partial decomposition to gold(0).

Table 1. Synthesis of 5,6-spiroketal 14 by gold(III) catalysed dihydroalkoxylation of alkynyl diol $7^{\mathrm{a}}$

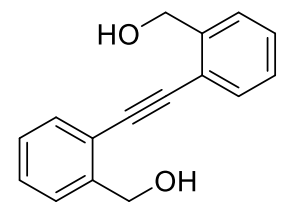

7

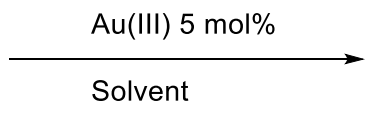

Solvent

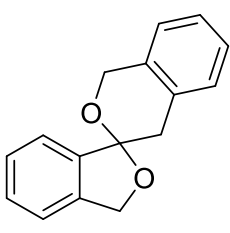

14

\begin{tabular}{|c|c|c|c|c|c|c|}
\hline Entry & Catalyst & Additive (mol\%) & Solvent & Time & Yield $^{\text {b }}$ & $\% e^{c}$ \\
\hline 1 & $11 a$ & & $\mathrm{CH}_{2} \mathrm{Cl}_{2}$ & $1 \mathrm{~h}$ & $84 \%$ & $1 \%$ \\
\hline 2 & $11 a$ & & $\mathrm{CH}_{3} \mathrm{CN}$ & $3 \mathrm{~h}$ & $76 \%$ & $0 \%$ \\
\hline 3 & $11 a$ & & THF & $3 \mathrm{~h}$ & $55 \%$ & $3 \%$ \\
\hline 4 & $11 a$ & & Toluene & $24 \mathrm{~h}$ & $63 \%$ & $0 \%$ \\
\hline 5 & $11 a$ & & $\mathrm{CH}_{3} \mathrm{NO}_{2}$ & $3 \mathrm{~h}$ & $87 \%$ & $1 \%$ \\
\hline 6 & $11 a$ & & Acetone & $5 \mathrm{~h}$ & $78 \%$ & $5 \%$ \\
\hline 7 & $11 a$ & $\mathrm{AgBF}_{4}(10 \%)$ & Acetone & $2 \mathrm{~h}$ & $86 \%$ & $0 \%$ \\
\hline 8 & $11 a$ & $\begin{array}{c}\text { S-Camphor- } \\
\text { sulfonic acid (10\%) }\end{array}$ & Acetone & $1 \mathrm{~h}$ & $93 \%$ & $1 \%$ \\
\hline 9 & 11b & & Acetone & $5 \mathrm{~h}$ & $42 \%$ & $2 \%$ \\
\hline
\end{tabular}


Table 1. Continued

\begin{tabular}{ccccccc}
\hline Entry & Catalyst & Additive (mol\%) & Solvent & Time & Yieldb & $\%$ eec \\
\hline 10 & 11c & Acetone & $4 \mathrm{~h}$ & $58 \%$ & $3 \%$ \\
11 & $11 d$ & Acetone & $2 \mathrm{~h}$ & $86 \%$ & $1 \%$ \\
12 & $11 \mathrm{e}$ & Acetone & $2 \mathrm{~h}$ & $70 \%$ & $0 \%$ \\
13 & 13 & Acetone & $30 \mathrm{~min}$ & $89 \%$ & $2 \%$ \\
\hline
\end{tabular}

${ }^{\text {a }}$ All reactions were performed with $0.10 \mathrm{mmol}$ substrate and 5 mol\% gold(III) catalyst in $5 \mathrm{~mL}$ solvent at room temperature.

${ }^{\mathrm{b}}$ Isolated yield.

${ }^{\mathrm{C}}$ Determined by chiral HPLC.

2. Non-symmetrical alkyne substrate. Spiroketal synthesis from alkynyl diols by transition metal catalysed dihydroalkoxylations often introduces regiochemistry concerns. Non-symmetrical substituted alkyne substrates, such as diol 9 (Table 2) may possibly form a mixture of two 5,6-spiroketal regioisomers, due to the presence of two different alkyne carbons that both potentially could become the spiroketal central carbon. $^{13,23,24,31}$ To explore the catalytic potential of our gold(III) catalysts, we therefore included a regioselectivity study of the cycloisomerization of alkynyl diol 9, which can possibly lead to two monobenzannulated 5,6-spiroketal regioisomers. Both the spiro[isobenzofuran-1,2'-pyran] 15 and the spiro[furan-2,3'-isochromane] 16 were formed (Table 2).

Moderate to high combined yields of spiroketal regioisomers $\mathbf{1 5}$ and $\mathbf{1 6}$ were obtained with all gold(III) complexes $11 \mathrm{a}, \mathbf{d}$,e and $\mathbf{1 3}$ in the tested solvent (50-91\% in acetone, $\mathrm{CH}_{2} \mathrm{Cl}_{2}$ and $\mathrm{CH}_{3} \mathrm{CN}$, entries 1-8). It is apparent from the study that both the nature of the catalyst and the solvent affect the product ratio 15:16. Nearly equimolar mixtures of products 15 and 16 were formed with BOX catalyst 11d,e and PYR-OX catalyst 13 in acetone (entries 4-6), while all $\mathrm{Au}(\mathrm{III})$ catalysts 11a,d,e and 13 favored the formation of isobenzofuran 15. However, up to 80:20 ratio of 15:16 was seen with both catalyst 11 a and 13 in $\mathrm{CH}_{2} \mathrm{Cl}_{2}$ (entries 2, 7). These regioselectivity results are consistent with previous studies with gold catalysts ${ }^{40,41}$, but opposite to what is reported by $\mathrm{Rh}$ and Ir catalysis ${ }^{13,42}$ where isochromane 16 is preferentially formed. Minor enantioselectivity of isobenzofuran 15 (5-6\% ee, entries 3,8$)$ was observed with catalysts 11 a and 13 in acetonitrile. 
Table 2. Synthesis of 5,6-spiroketal regioisomers 15 and 16 by gold(III) catalysed dihydroalkoxylation of alkynyl diol $9^{a}$

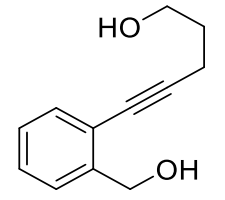

9

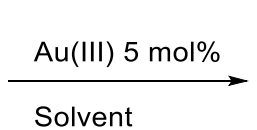

Solvent

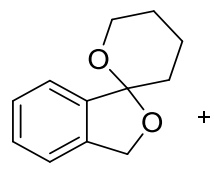

15

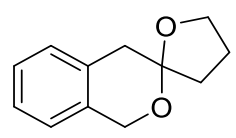

16

\begin{tabular}{|c|c|c|c|c|c|c|}
\hline Entry & Catalyst & Solvent & Time & Yield $^{b}$ & $\begin{array}{l}\text { Ratio } \\
15: 16\end{array}$ & $\% \mathrm{ee}^{\mathrm{c}}$ \\
\hline \multirow[t]{2}{*}{1} & $11 a$ & Acetone & $2 \mathrm{~h}$ & $85 \%$ & $74: 26$ & $5 \%(15)$ \\
\hline & & & & & & $2 \%(16)$ \\
\hline \multirow[t]{2}{*}{2} & $11 a$ & $\mathrm{CH}_{2} \mathrm{Cl}_{2}$ & $20 \mathrm{~min}$ & $87 \%$ & $80: 20$ & $0 \%(15)$ \\
\hline & & & & & & $3 \%(16)$ \\
\hline \multirow[t]{2}{*}{3} & $11 a$ & $\mathrm{CH}_{3} \mathrm{CN}$ & $1 \mathrm{~h}$ & $67 \%$ & $60: 40$ & $6 \%(15)$ \\
\hline & & & & & & $3 \%(16)$ \\
\hline \multirow[t]{2}{*}{4} & 11d & Acetone & $30 \mathrm{~min}$ & $70 \%$ & $58: 42$ & $0 \%$ \\
\hline & & & & & & $(15,16)$ \\
\hline \multirow[t]{2}{*}{5} & $11 e$ & Acetone & $30 \mathrm{~min}$ & $90 \%$ & $55: 45$ & $0 \%$ \\
\hline & & & & & & $(15,16)$ \\
\hline \multirow[t]{2}{*}{6} & 13 & Acetone & $15 \mathrm{~min}$ & $66 \%$ & $50: 50$ & $3 \%(15)$ \\
\hline & & & & & & $1 \%(16)$ \\
\hline \multirow[t]{2}{*}{7} & 13 & $\mathrm{CH}_{2} \mathrm{Cl}_{2}$ & $15 \mathrm{~min}$ & $50 \%$ & $77: 23$ & $2 \%(15)$ \\
\hline & & & & & & $2 \%(16)$ \\
\hline \multirow[t]{2}{*}{8} & 13 & $\mathrm{CH}_{3} \mathrm{CN}$ & $15 \mathrm{~min}$ & $91 \%$ & $55: 45$ & $5 \%(15)$ \\
\hline & & & & & & $3 \%(16)$ \\
\hline
\end{tabular}

a All reactions were performed with $0.10 \mathrm{mmol}$ substrate and $5 \mathrm{~mol} \%$ gold(III) catalyst in $5 \mathrm{~mL}$ solvent at room temperature.

${ }^{\mathrm{b}}$ Isolated combined yield of $\mathbf{1 5}$ and $\mathbf{1 6 .}$

${ }^{\mathrm{c}}$ Determined by chiral HPLC.

3. Spirocentre enantioselectivity. Only a few asymmetric approaches are known for the preparation of chiral spiroketals. ${ }^{26-32}$ One successful strategy has demonstrated that chiral phosphoric acids (CPAs) may serve as effective catalysts for enantioselective spiroketalizations. ${ }^{43}$ Despite the chiral nature of the Au(III)-BOX and $\mathrm{Au}(\mathrm{III})$-PYR-OX catalysts 11 and 13, no enantioselectivity was obtained in our previous catalytic studies of alkoxycyclizations or in cyclopropanation reactions. ${ }^{47,49}$ Other reports also indicate that this type of bidentate ligands does not give any enantioselectivity when a complex with a square planar geometry is involved, independently of the metal. ${ }^{44-46}$

On this background, our expectations to obtain asymmetric synthesis of benzannulated spiroketals using chiral $\mathrm{Au}(\mathrm{III})$-oxazoline catalysts were limited. Therefore, the present observations of minor enantioselectivity (up to $6 \%$ ) generated with $\mathrm{Au}(\mathrm{III})$ catalysts $11 \mathrm{a}$ and $\mathbf{1 3}$ is remarkable, being the first of our $\mathrm{Au}(\mathrm{III})$ complexes that provide detectable enantioselectivity. 


\section{Mechanism}

The mechanism of the gold catalysed intramolecular tandem dihydroalkoxylation of alkynyl diol 7 to spiroketal 14 is postulated ${ }^{31}$ to start by $\pi$-coordination of the gold catalyst to the alkyne (7) by forming $\mathrm{Au}(\mathrm{III})$ activated alkyne $\mathbf{A}$ (Scheme 4). The first cyclisation may proceed via either a 6-endo-dig or a 5-exo-dig process to give endo-B and exo-B monocyclic intermediates, respectively. Two alternative pathways a) and b) may describe the final spiroketalization. Proton shift would yield the prochiral cyclic oxocarbenium Au(III) species endo-C and exo-C, which may readily undergo spirocyclization by the second nucleophilic attack of the pendant alcohol group to form gold-coordinated spiroketal $\mathbf{D}$ from both intermediates (Scheme 4a). Formation of the stereogenic spirocentre takes place in this step and potential enantioselective ring closure may be induced by the chiral $\mathrm{Au}(\mathrm{III})$ coordinated unit. Protodeauration yields the target spiroketal product 14.

a)
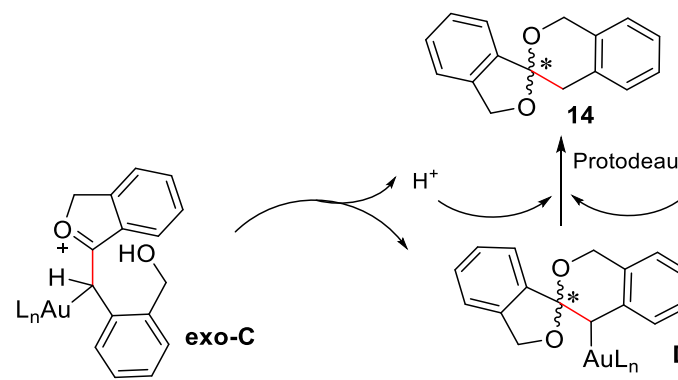

$\uparrow$ Protodeauration

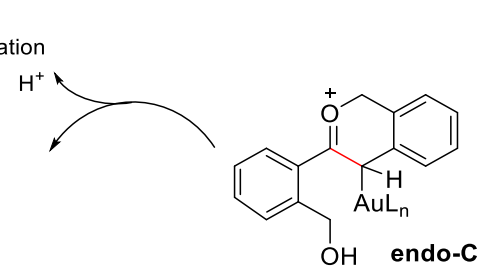
$\mathrm{H}^{+}$shift
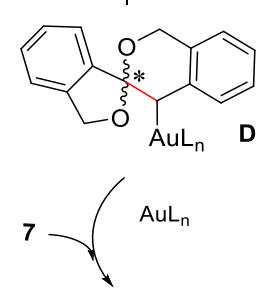

$\| \mathrm{H}^{+}$shift
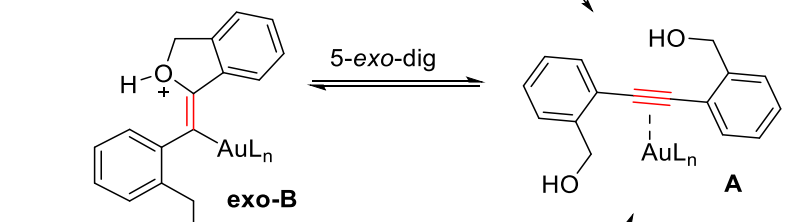

-dig

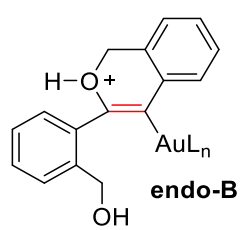

b)

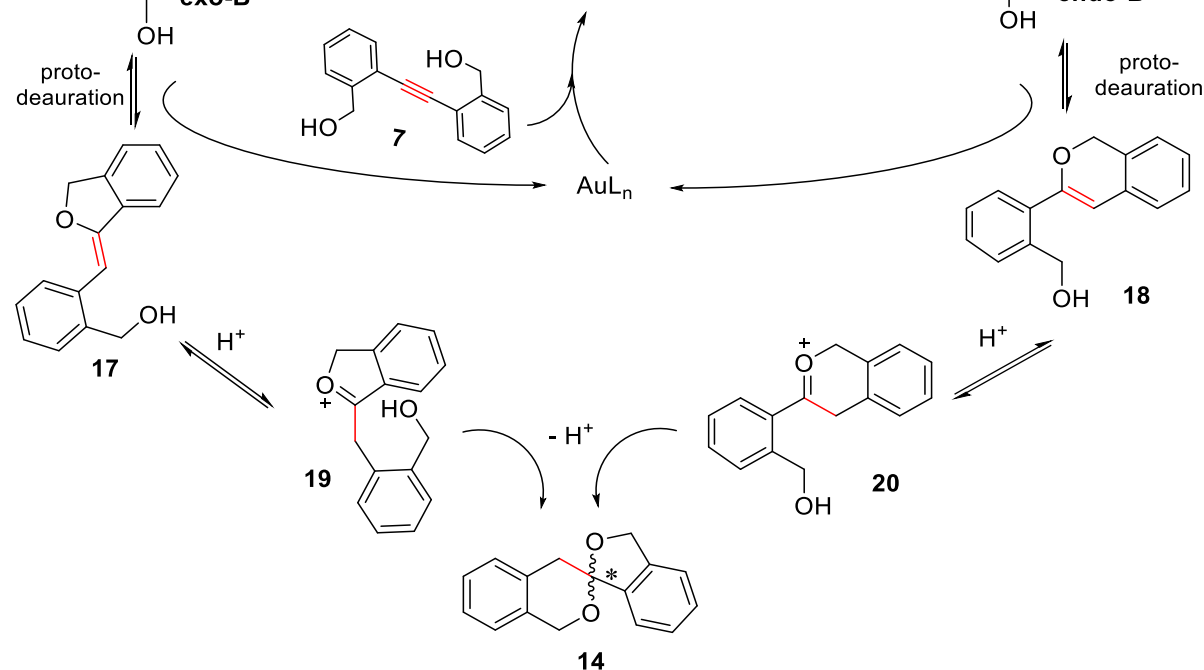

Scheme 4. Proposed mechanisms a), b) for gold catalysed dihydroalkoxylation of alkynyl diol 7 to give 5,6spiroketal 14 (red C-C bonds represent original alkyne position).

An alternative mechanism ${ }^{54}$ (Scheme $4 \mathrm{~b}$ ) is based on the opposite order of the two steps from intermediates endo-/exo-B, which may undergo direct protodeauration to form vinyl ethers $\mathbf{1 7}$ and $\mathbf{1 8}$. Indeed, vinyl ethers $\mathbf{1 7}$ and $\mathbf{1 8}$ could be detected by NMR analysis of reaction samples and vinyl ether $\mathbf{1 8}$ was isolated from incomplete reaction mixtures. Protonation of the vinyl ethers leads to the oxocarbenium ions 19 
and 20, which would quickly undergo nucleophilic attack and 6-/5-exo-dig spirocyclization to give spiroketal 14 with no expected enantioselectivity, due to the absence of a stereocontrolling gold moiety. In previous studies of similar Au(I)-NHC catalysed reactions, the final step is suggested to be entirely acid catalysed. ${ }^{40}$

The experimental results do not fully confirm either of the mechanistic pathways a), b). ${ }^{40,45}$ Complete conversion of the alkynyl diol 7 gave a mixture of spiroketal 14 and vinyl ether $\mathbf{1 8}$ (NMR) within minutes for all $\mathrm{Au}(\mathrm{III})$-BOX catalysts 11a-e, but further conversion of vinyl ether $\mathbf{1 8}$ to spiroketal $\mathbf{1 4}$ was slow and indicates that the final cyclisation to form spiroketal $\mathbf{1 4}$ is the rate limiting step of these tandem reactions. No increase of reaction rate was seen by addition of more catalyst to the mixture, which could indicate that the final step might be catalysed by trace amounts of acid. Contradictory results were obtained, applying Au(III)-PYR-OX complex 13, as full tandem conversion of the original diol substrate 7 to target product 14 was seen within 30 min (Table 1, entry 13, Scheme 5b), while, in contrast, a test cyclization reaction of purified vinyl ether 18 only gave $61 \%$ conversion to spiroketal 14 ( 0 \% ee, Scheme $5 a$ ) and a complex mixture of new minor products.

As the final cyclisation is the enantiodetermining cyclization step, a completely racemic spiroketal product would be expected if a gold adduct is not involved (e.g. 19, 20; mechanism b). The gold catalysed test reaction of the final cyclization of vinyl ether $\mathbf{1 8}$ did actually afford full racemization (Scheme 5a), possibly due to de-coordination of an oxazoline or pyridine moiety, as observed and discussed in our previous catalytic studies with catalyst $13 .{ }^{33}$ The fact that some enantioselectivity (up to $5 \%$ ee) was observed through the complete tandem spirocyclization pathway from diol substrate $\mathbf{7}$ to target product 14, may indicate that the spirocyclization mechanism, catalyzed by $\mathrm{Au}(\mathrm{III})$-oxazoline complexes, is more complex than previously suggested. $^{31,40}$

a)

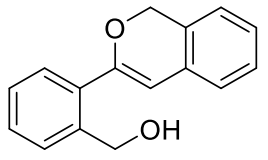

18

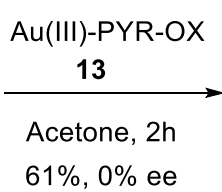

$61 \%, 0 \%$ ee

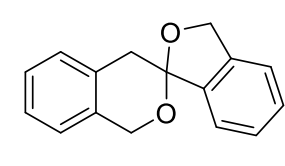

14 b)

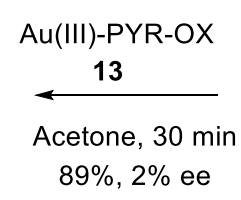

$89 \%, 2 \%$ ee

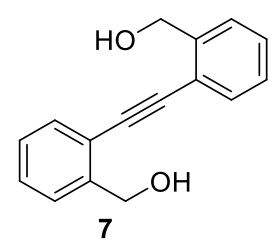

Scheme 5. Spiroketalization of vinyl ether 18 and alkynyl diol 7 to form 5,6-spiroketal 14 by a) mono- and b) dihydroalkoxylation, respectively.

\section{Conclusions}

The present first known study on gold(III)-oxazoline catalysed tandem spiroketalization shows that Au(III)-BOX (11a-e) and Au(III)-PYR-OX (13) complexes are highly efficient catalyst for intramolecular dihydroalkoxylation of alkynyl diols $(7,9)$ to give aromatic 5,6-spiroketal products (14 and 15/16). The mono- and dibenzannulated spiroketals (14 and 15/16) were obtained in high yields (> $90 \%$ ) by rapid conversion of symmetrical and nonsymmetrical alkynyl diols, respectively $(7,9)$. Minor enantioselectivity (up to $6 \%$ ee) was observed with the $\mathrm{Au}(\mathrm{III})-\mathrm{BOX}_{-}-\mathrm{BF}_{4}$ and $\mathrm{Au}(\mathrm{III})-\mathrm{PYR}-\mathrm{OX}$ catalysts $(\mathbf{1 1 a}, \mathbf{1 3})$. The monobenzannulated 5,6-spiroketal regioisomers 15 and $\mathbf{1 6}$ were formed in a ratio of up to 80:20. The choice of solvent seemed to be particularly important for the yields, enantio- and regioselectivity of the reactions of alkynyl diols $(\mathbf{7 , 9}$ ). The tandem mechanism for spirocyclization is discussed. 


\section{Experimental Section}

General. Commercial grade reagents were used without any additional purification. Dry solvents were collected from an MB SPS- 800 solvent purification system. Reactions were monitored by NMR and/or thinlayer chromatography (TLC) using silica gel $60 \mathrm{~F} 254$ (0.25 mm thickness). TLC plates were developed using UVlight and/or phosphomolybdic acid stain. Flash chromatography was performed with Merck silica gel 60 (0.040-0.063 mm). ${ }^{1} \mathrm{H}$ and ${ }^{13} \mathrm{C}$ NMR spectra were recorded with a Bruker Avance DPX $400 \mathrm{MHz}$ spectrometer. Chemical shifts are reported in ppm ( $\delta$ ) downfield from tetramethylsilane (TMS) as an internal standard. Accurate mass determination was performed on a "Synapt G2-S" Q-TOF instrument from Waters. Samples were ionized with an ASAP probe with no chromatography separation performed before mass analysis. Chiral HPLC was used for enantio-determination (\% ee) with CHIRALPAK AD-H and OJ-H columns with $i$-PrOH:hexane eluents and flow rate $0.800 \mathrm{~mL} / \mathrm{min}$.

\section{General procedure for Sonogashira cross-coupling}

A dried two-neck flask was charged with (2-iodophenyl)methanol 4 (1 eq), the appropriate alkyne (1 eq), $\left(\mathrm{PPh}_{3}\right)_{2} \mathrm{PdCl}_{2}(0.05 \mathrm{eq})$ and $\mathrm{Cul}(0.10 \mathrm{eq})$ under an $\mathrm{N}_{2}$-atmosphere. Dry, de-gassed THF was then added, followed by $\mathrm{Et}_{3} \mathrm{~N}(2 \mathrm{eq})$. The solution was stirred at room temperature for $16 \mathrm{~h}$. The reaction mixture was filtered through celite and added EtOAc. The organic phase was washed twice with sat. $\mathrm{NH}_{4} \mathrm{Cl}$ solution, followed by brine. After drying over anhydrous $\mathrm{Na}_{2} \mathrm{SO}_{4}$ and filtration, silica gel was added to the crude product solution, followed by drying in vacuo. Purification by column chromatography (pentane:EtOAc) yielded the final products.

2-((2-(Hydroxymethyl)phenyl)ethynyl)benzaldehyde (6). Following the general procedure, 2ethynylbenzaldehyde $(5,319 \mathrm{mg}, 2.45 \mathrm{mmol})$ and (2-iodophenyl)methanol $(4,574 \mathrm{mg}, 2.45 \mathrm{mmol})$ gave the target product 6 as an orange oil in $75 \%$ yield ( $431 \mathrm{mg}, 1.84 \mathrm{mmol}) .{ }^{1} \mathrm{H} \mathrm{NMR}\left(400 \mathrm{MHz}, \mathrm{CDCl}_{3}\right) \delta(\mathrm{ppm}) 10.50$ (s, $1 \mathrm{H}, \mathrm{CHO}$ ), 7.90 (dd, J 7.8, $\left.1.3 \mathrm{~Hz}, 1 \mathrm{H}, \mathrm{CH}_{\mathrm{Ar}}\right), 7.64\left(\mathrm{dd}, J 7.8,1.1 \mathrm{~Hz}, 1 \mathrm{H}, \mathrm{CH}_{\mathrm{Ar}}\right), 7.58\left(\mathrm{td}, 7.5,1.1 \mathrm{~Hz}, 1 \mathrm{H}, \mathrm{CH}_{\mathrm{Ar}}\right.$ ), 7.55 (dd, J 7.6, $\left.1.0 \mathrm{~Hz}, 1 \mathrm{H}, \mathrm{CH}_{\mathrm{Ar}}\right), 7.44-7.50\left(\mathrm{~m}, 2 \mathrm{H}, \mathrm{CH}_{\mathrm{Ar}}\right), 7.38$ (td, J 7.5, $\left.1.4 \mathrm{~Hz}, 1 \mathrm{H}, \mathrm{CH}_{\mathrm{Ar}}\right), 7.29$ (td, J 7.5, $1.0 \mathrm{~Hz}$, $\left.1 \mathrm{H}, \mathrm{CH}_{\mathrm{Ar}}\right), 4.90\left(\mathrm{~d}, J 6.0 \mathrm{~Hz}, 2 \mathrm{H}, \mathrm{CH}_{2}\right), 2.96(\mathrm{t}, J 6.2 \mathrm{~Hz}, 1 \mathrm{H}, \mathrm{OH}) .{ }^{1} \mathrm{H}$ NMR data corresponds to previously reported data. ${ }^{47}$

(Ethyne-1,2-diylbis(2,1-phenylene))dimethanol (7). 2-((2-(Hydroxymethyl)phenyl)ethynyl)benzaldehyde (6, $242 \mathrm{mg}, 1.02 \mathrm{mmol})$, was dissolved in ethanol $(5 \mathrm{~mL})$. To the solution was added $\mathrm{NaBH}_{4}(116 \mathrm{mg}, 3.07 \mathrm{mmol})$ and the solution was stirred for $30 \mathrm{~min}$. The reaction was quenched by addition of a $\mathrm{HCl}$ solution $(1 \mathrm{M}, 25 \mathrm{~mL})$ and the product extracted into EtOAc $(2 \times 25 \mathrm{~mL})$. The organic phase was washed with brine, followed by drying over anhydrous $\mathrm{Na}_{2} \mathrm{SO}_{4}$ and evaporation in vacuo. Purification by column chromatography (2:1 pentane:EtOAc) gave the target product 7 as a white solid in $57 \%$ yield (139 mg, $0.581 \mathrm{mmol}$ ). ${ }^{1} \mathrm{H}$ NMR (400 $\left.\mathrm{MHz}, \mathrm{CDCl}_{3}\right) \delta(\mathrm{ppm}) 7.58\left(\mathrm{dd}, J 7.2,1.5 \mathrm{~Hz}, 2 \mathrm{H}, \mathrm{CH}_{\mathrm{Ar}}\right), 7.43$ (dd, J 7.5, $\left.1.7 \mathrm{~Hz}, 2 \mathrm{H}, \mathrm{CH}_{\mathrm{Ar}}\right), 7.30-7.38\left(\mathrm{~m}, 4 \mathrm{H}, \mathrm{CH}_{\mathrm{Ar}}\right)$, $4.87\left(\mathrm{~d}, J 3.5 \mathrm{~Hz}, 4 \mathrm{H}, \mathrm{CH}_{2}\right.$ ), 2.74 (broad s, $2 \mathrm{H}, \mathrm{OH}$ ). ${ }^{1} \mathrm{H}$ NMR data corresponds to previously reported data. ${ }^{48}$

5-(2-(Hydroxymethyl)phenyl)pent-4-yn-1-ol (9). Following the general procedure, pent-4-yn-1-ol (8, $219 \mathrm{mg}$, $2.61 \mathrm{mmol})$ and (2-iodophenyl)methanol $(4,610 \mathrm{mg}, 2.61 \mathrm{mg})$ gave the target product 9 as an orange solid in $91 \%$ yield $(450 \mathrm{mg}, 2.38 \mathrm{mmol}) .{ }^{1} \mathrm{H} \mathrm{NMR}\left(400 \mathrm{MHz}, \mathrm{CDCl}_{3}\right) \delta(\mathrm{ppm}) 7.38-7.42\left(\mathrm{~m}, 2 \mathrm{H}, \mathrm{CH}_{\mathrm{Ar}}\right), 7.29(\mathrm{td}$, J 7.5. 1.4 $\left.\mathrm{Hz}, 1 \mathrm{H}, \mathrm{CH}_{\mathrm{Ar}}\right), 7.23\left(\mathrm{td}, J \mathrm{~J} .5,1.4 \mathrm{~Hz}, 1 \mathrm{H}, \mathrm{CH}_{\mathrm{Ar}}\right), 4.79\left(\mathrm{~s}, 2 \mathrm{H}, \mathrm{CH}_{2}\right), 3.84\left(\mathrm{t}, \mathrm{J} 5.9 \mathrm{~Hz}, 2 \mathrm{H}, \mathrm{CH}_{2}\right), 2.60(\mathrm{t}, J 6.9 \mathrm{~Hz}, 2 \mathrm{H}$, $\mathrm{CH}_{2}$ ), 2.33 (bs, $\left.1 \mathrm{H}, \mathrm{OH}\right), 1.88\left(\mathrm{p}, J 6.4 \mathrm{~Hz}, 2 \mathrm{H}, \mathrm{CH}_{2}\right), 1.73$ (bs, $\left.1 \mathrm{H}, \mathrm{OH}\right) .{ }^{1} \mathrm{H}$ NMR data corresponds to previously reported data. ${ }^{13}$ 


\section{General procedure for the synthesis of gold(III) complexes}

To a solution of the appropriate ligand (1 eq) in $\mathrm{CH}_{3} \mathrm{CN}$ was added $\mathrm{AuCl}_{3}(1 \mathrm{eq})$ and the appropriate silver salt ( 1 eq). The resulting solution was stirred at room temperature for 1 hour, followed by filtration through celite and evaporation in vacuo. The crude product was redissolved in DCM and the organic phase washed once each with water and brine followed by drying over anhydrous $\mathrm{Na}_{2} \mathrm{SO}_{4}$ and the volume of solvent was reduced in vacuo to approx $1 \mathrm{~mL}$. The complexes were precipitated out of solution by addition of Et ${ }_{2} \mathrm{O}$, after which filtration gave the pure complexes as crystalline solids.

i-Pr-BOX-Au-BF 4 (11a). Following the general procedure, ligand 10a (39.2 mg, $0.147 \mathrm{mmol}), \mathrm{AuCl}_{3}$ (44.6 mg, $0.147 \mathrm{mmol}$ ) and $\mathrm{AgBF}_{4}(28.6 \mathrm{mg}, 0.147 \mathrm{mmol})$ gave complex 11a as yellow crystals in $47 \%$ yield (43.4 mg, $0.0691 \mathrm{mmol}) .{ }^{1} \mathrm{H}$ NMR $\left(400 \mathrm{MHz}, \mathrm{CDCl}_{3}\right) \delta(\mathrm{ppm}) 5.00(\mathrm{dt}, J 9.3,3.2 \mathrm{~Hz}, 2 \mathrm{H}, \mathrm{CH}), 4.88\left(\mathrm{t}, J 9.2 \mathrm{~Hz}, 2 \mathrm{H}, \mathrm{CH}_{2}\right), 4.71$ (dd, J 9.2, 3.3 Hz, 2H, CH$\left.)_{2}\right), 2.62(\mathrm{~m}, 2 \mathrm{H}, \mathrm{CH}), 1.85\left(\mathrm{~s}, 6 \mathrm{H}, \mathrm{CH}_{3}\right), 0.97\left(\mathrm{~d}, J 7.2 \mathrm{~Hz}, 6 \mathrm{H}, \mathrm{CH}_{3}\right), 0.87(\mathrm{~d}, J 6.8 \mathrm{~Hz}, 6 \mathrm{H}$, $\left.\mathrm{CH}_{3}\right) .{ }^{1} \mathrm{H}$ NMR data corresponds to previously reported data. ${ }^{33}$

i-Pr-BOX-Au-SbF $\mathbf{6}$ (11b). Following the general procedure, ligand 10a (69.0 mg, $0.259 \mathrm{mmol}), \mathrm{AuCl}_{3}(78.6 \mathrm{mg}$, $0.259 \mathrm{mmol}$ ) and $\mathrm{AgSbF}_{6}(89.0 \mathrm{mg}, 0.259 \mathrm{mmol}$ ) gave complex 11b as yellow crystals in $50 \%$ yield (100.4 mg, $0.130 \mathrm{mmol}) .{ }^{1} \mathrm{H}$ NMR $\left(400 \mathrm{MHz}, \mathrm{CD}_{3} \mathrm{CN}\right) \delta(\mathrm{ppm}) 4.92(\mathrm{dt}, J 9.4,2.9 \mathrm{~Hz}, 2 \mathrm{H}, \mathrm{CH}), 4.86(\mathrm{dd}, J 9.6,3.1 \mathrm{~Hz}, 2 \mathrm{H}$, $\mathrm{CH}_{2}$ ), 4.67(t, J $9.5 \mathrm{~Hz}, 2 \mathrm{H}, \mathrm{CH}_{2}$ ), 2.49 (ds, J 7.0, $\left.2.6 \mathrm{~Hz}, 2 \mathrm{H}, \mathrm{CH}\right), 1.76\left(\mathrm{~s}, 6 \mathrm{H}, \mathrm{CH}_{3}\right), 0.94\left(\mathrm{~d}, \mathrm{~J} 7.0 \mathrm{~Hz}, 6 \mathrm{H}, \mathrm{CH}_{3}\right), 0.82$ $\left(\mathrm{d}, \mathrm{J} 7.0 \mathrm{~Hz}, 6 \mathrm{H}, \mathrm{CH}_{3}\right) .{ }^{1} \mathrm{H} \mathrm{NMR}$ data corresponds to previously reported data. ${ }^{33}$

i-Pr-BOX-Au-NTf $\mathbf{2}_{\mathbf{2}}$ (11c). Following the general procedure, ligand 10a (53.1 mg, $\left.0.199 \mathrm{mmol}\right), \mathrm{AuCl}_{3}(60.5 \mathrm{mg}$, $0.199 \mathrm{mmol}$ ) and $\mathrm{AgNTf}_{2}(77.3 \mathrm{mg}, 0.199 \mathrm{mmol}$ ) gave complex 11c as yellow crystals in $73 \%$ yield (118.1 mg, $0.146 \mathrm{mmol}) .{ }^{1} \mathrm{H}$ NMR $\left(400 \mathrm{MHz}, \mathrm{CD}_{3} \mathrm{CN}\right) \delta(\mathrm{ppm}) 4.93(\mathrm{dt}, \mathrm{J} 9.3,2.6 \mathrm{~Hz}, 2 \mathrm{H}, \mathrm{CH}), 4.86(\mathrm{dd}, \mathrm{J} 9.8,3.2 \mathrm{~Hz}, 2 \mathrm{H}$, $\mathrm{CH}_{2}$ ), 4.70 (t, J $9.6 \mathrm{~Hz}, 2 \mathrm{H}, \mathrm{CH}_{2}$ ), 2.49 (ds, J 7.0, $\left.2.8 \mathrm{~Hz}, 2 \mathrm{H}, \mathrm{CH}\right), 1.76\left(\mathrm{~s}, 6 \mathrm{H}, \mathrm{CH}_{3}\right), 0.95\left(\mathrm{~d}, J 7.0 \mathrm{~Hz}, 6 \mathrm{H}, \mathrm{CH}_{3}\right)$, $0.82\left(\mathrm{~d}, J 6.9 \mathrm{~Hz}, 6 \mathrm{H}, \mathrm{CH}_{3}\right) .{ }^{13} \mathrm{C} \mathrm{NMR}\left(100 \mathrm{MHz}, \mathrm{CD}_{3} \mathrm{CN}\right) \delta(\mathrm{ppm}) 175.2(\mathrm{C}=\mathrm{N}), 73.1\left(\mathrm{CH}_{2}\right), 71.4(\mathrm{CH}), 30.9(\mathrm{CH})$, $25.7\left(\mathrm{CH}_{3}\right), 18.0\left(\mathrm{CH}_{3}\right), 13.7\left(\mathrm{CH}_{3}\right)$. HRMS (ESI) $\mathrm{m} / z$ [M ${ }^{+}$]: calcd. for $\mathrm{C}_{15} \mathrm{H}_{26} \mathrm{AuCl}_{2} \mathrm{~N}_{2} \mathrm{O}_{2}$ 533.1037, found 533.1046.

$\mathbf{P h}_{-B O X-A u-B_{4}}$ (11d). Following the general procedure, ligand 10b (44.9 mg, $\left.0.134 \mathrm{mmol}\right), \mathrm{AuCl}_{3}(40.7 \mathrm{mg}$, $0.134 \mathrm{mmol}$ ) and $\mathrm{AgBF}_{4}(26.1 \mathrm{mg}, 0.134 \mathrm{mmol})$ gave complex 11d as yellow crystals in $95 \%$ yield (88.2 mg, $0.128 \mathrm{mmol}) .{ }^{1} \mathrm{H}$ NMR $\left(400 \mathrm{MHz}, \mathrm{CD}_{3} \mathrm{CN}\right) \delta(\mathrm{ppm})$ 7.41-7.49 (m, 6H, $\left.\mathrm{CH}_{\mathrm{Ar}}\right), 7.33-7.36\left(\mathrm{~m}, 4 \mathrm{H}, \mathrm{CH}_{\mathrm{Ar}}\right), 6.05(\mathrm{dd}, J$ 10.1, $4.9 \mathrm{~Hz}, 2 \mathrm{H}, \mathrm{CH}), 5.18\left(\mathrm{t}, J 9.5 \mathrm{~Hz}, 2 \mathrm{H}, \mathrm{CH}_{2}\right), 4.74\left(\mathrm{dd}, J 9.3,4.8 \mathrm{~Hz}, 2 \mathrm{H}, \mathrm{CH}_{2}\right), 2.03\left(\mathrm{~s}, 6 \mathrm{H}, \mathrm{CH}_{3}\right) .{ }^{1} \mathrm{H} N M R$ data corresponds to previously reported data. ${ }^{33}$

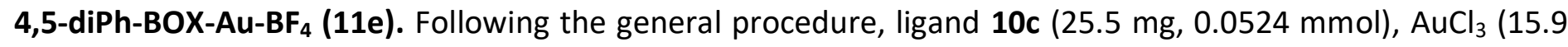
$\mathrm{mg}, 0.0524 \mathrm{mmol}$ ) and $\mathrm{AgBF}_{4}(10.2 \mathrm{mg}, 0.0524 \mathrm{mmol}$ ) gave complex 11d as yellow crystals in $89 \%$ yield (39.4 $\mathrm{mg}, 0.468 \mathrm{mmol}) .{ }^{1} \mathrm{H}$ NMR $\left(400 \mathrm{MHz}, \mathrm{CD}_{3} \mathrm{CN}\right) \delta(\mathrm{ppm})$ 7.13-7.22 (m, 16H, $\left.\mathrm{CH}_{\mathrm{Ar}}\right), 7.03-7.06\left(\mathrm{~m}, 4 \mathrm{H}, \mathrm{CH}_{\mathrm{Ar}}\right), 6.60$ $(\mathrm{d}, J 9.8 \mathrm{~Hz}, 2 \mathrm{H}, \mathrm{CH}), 6.47(\mathrm{~d}, J 9.8 \mathrm{~Hz}, 2 \mathrm{H}, \mathrm{CH}), 2.26\left(\mathrm{~s}, 6 \mathrm{H}, \mathrm{CH}_{3}\right) .{ }^{13} \mathrm{C} \mathrm{NMR}\left(100 \mathrm{MHz}, \mathrm{CD}_{3} \mathrm{CN}\right) \delta(\mathrm{ppm}) 176.9$ $(\mathrm{C}=\mathrm{N}), 134.4\left(\mathrm{C}_{\mathrm{Ar}}\right), 132.1\left(\mathrm{C}_{\mathrm{Ar}}\right), 130.1\left(\mathrm{CH}_{\mathrm{Ar}}\right), 129.6\left(\mathrm{CH}_{\mathrm{Ar}}\right), 129.4\left(\mathrm{CH}_{\mathrm{Ar}}\right), 129.1\left(\mathrm{CH}_{\mathrm{Ar}}\right), 128.5\left(\mathrm{CH}_{\mathrm{Ar}}\right), 127.8\left(\mathrm{CH}_{\mathrm{Ar}}\right)$, $91.2(\mathrm{CH}), 73.6(\mathrm{CH}), 44.0(\mathrm{C}), 26.1\left(\mathrm{CH}_{3}\right)$. HRMS (ESI) $\mathrm{m} / z\left[\mathrm{M}^{+}\right]$: calcd. for $\mathrm{C}_{33} \mathrm{H}_{30} \mathrm{AuCl}_{2} \mathrm{~N}_{2} \mathrm{O}_{2}$ 753.1350, found 753.1360.

PYR-OX-Au-BF 4 (13). Following the general procedure, ligand 12 (25.0 mg, $0.122 \mathrm{mmol}), \mathrm{AuCl}_{3}(37.1 \mathrm{mg}, 0.122$ mmol) and $\mathrm{AgBF}_{4}(23.8 \mathrm{mg}, 0.122 \mathrm{mmol})$ gave complex 13 as yellow crystals in $79 \%$ yield (54.1 mg, 0.0965 mmol). ${ }^{1} \mathrm{H}$ NMR (400 MHz, CD $\mathrm{CCN} \delta(\mathrm{ppm}) 9.42$ (dd, J 5.8, $\left.0.8 \mathrm{~Hz}, 1 \mathrm{H}, \mathrm{CH}_{\mathrm{Ar}}\right), 8.64\left(\mathrm{td}, J 7.7,1.1 \mathrm{~Hz}, 1 \mathrm{H}, \mathrm{CH}_{\mathrm{Ar}}\right)$, 8.29 (dd, J 7.8, 1.5 Hz, 1H, $\mathrm{CH}_{\mathrm{Ar}}$ ), 8.24 (ddd, J 7.6, 5.8, 1.4 Hz, 1H, CH $\mathrm{Ar}_{\text {) }}, 5.43$ (dd, J 10.0, 2.7 Hz, $1 \mathrm{H}, \mathrm{CH}_{2}$ ), 5.11 $\left(\mathrm{dd}, J\right.$ 9.9, $\left.8.9 \mathrm{~Hz}, 1 \mathrm{H}, \mathrm{CH}_{2}\right), 4.54(\mathrm{dd}, J 8.9,2.7 \mathrm{~Hz}, 1 \mathrm{H}, \mathrm{CH}), 1.06\left(\mathrm{~s}, 9 \mathrm{H}, \mathrm{CH}_{3}\right) .{ }^{1} \mathrm{H} \mathrm{NMR}$ data corresponds to previously reported data. ${ }^{35}$ 


\section{General procedure for the dihydroalkoxylation of alkynyl diols}

Alkynyl diol 7/9 (1 eq) was dissolved in the appropriate solvent and the gold catalyst (0.05 eq) was added. The reaction was monitored either by TLC chromatography or by ${ }^{1} \mathrm{H}$ NMR of reaction mixture aliquots. When the reaction was complete, the solvent was evaporated in vacuo. Purification by column chromatography (pentane:EtOAc) yielded the spiroketals 14-16.

3H-Spiro[isobenzofuran-1,3'-isochromane] (14). Results are as shown in Table 1. ${ }^{1} \mathrm{H} \mathrm{NMR}\left(400 \mathrm{MHz} \mathrm{CDCl}_{3}\right) \delta$ (ppm) $7.39\left(\mathrm{dq}, J 6.9,1.9 \mathrm{~Hz}, 1 \mathrm{H}, \mathrm{CH}_{\mathrm{Ar}}\right), 7.30-7.36\left(\mathrm{~m}, 3 \mathrm{H}, \mathrm{CH}_{\mathrm{Ar}}\right), 7.21-7.24\left(\mathrm{~m}, 2 \mathrm{H}, \mathrm{CH}_{\mathrm{Ar}}\right), 7.16-7.20(\mathrm{~m}, 1 \mathrm{H}$, $\left.\mathrm{CH}_{\mathrm{Ar}}\right), 7.08-7.10\left(\mathrm{~m}, 1 \mathrm{H}, \mathrm{CH}_{\mathrm{Ar}}\right), 5.25\left(\mathrm{~d}, J 12.7 \mathrm{~Hz}, 1 \mathrm{H}, \mathrm{CH}_{2}\right), 5.15\left(\mathrm{~d}, J 14.7 \mathrm{~Hz}, 1 \mathrm{H}, \mathrm{CH}_{2}\right), 5.07(\mathrm{~d}, J 12.7 \mathrm{~Hz}, 1 \mathrm{H}$, $\mathrm{CH}_{2}$ ), $4.86\left(\mathrm{~d}, J 14.8 \mathrm{~Hz}, 1 \mathrm{H}, \mathrm{CH}_{2}\right), 3.57\left(\mathrm{~d}, J 16.2 \mathrm{~Hz}, 1 \mathrm{H}, \mathrm{CH}_{2}\right), 3.07\left(\mathrm{~d}, J 16.3 \mathrm{~Hz}, 1 \mathrm{H}, \mathrm{CH}_{2}\right)$. HPLC: CHIRALPAK AD$\mathrm{H}$, UV-detector: $210 \mathrm{~nm}$ eluent: $i-\mathrm{PrOH}$ :hexane 97:3, retention time: $10.64 \mathrm{~min}, 13.39 \mathrm{~min} .{ }^{1} \mathrm{H} \mathrm{NMR}$ data corresponds to previously reported data. ${ }^{13}$

3',4',5',6'-Tetrahydro-3H-spiro[isobenzofuran-1,2'-pyran] (15). Results are as shown in Table 2. Isolated as a mixture of spiroketals 15 and 16. ${ }^{1} \mathrm{H}$ NMR $\left(400 \mathrm{MHz}, \mathrm{CDCl}_{3}\right) \delta(\mathrm{ppm}) 7.13-7.17\left(\mathrm{~m}, 2 \mathrm{H}, \mathrm{CH}_{\mathrm{Ar}}\right), 7.07-7.10(\mathrm{~m}, 1 \mathrm{H}$, $\left.\mathrm{CH}_{\mathrm{Ar}}\right), 6.99-7.02\left(\mathrm{~m}, 1 \mathrm{H}, \mathrm{CH}_{\mathrm{Ar}}\right), 4.92\left(\mathrm{~d}, J 14.8 \mathrm{~Hz}, 1 \mathrm{H}, \mathrm{CH}_{2}\right), 4.67\left(\mathrm{~d}, J 14.8 \mathrm{~Hz}, 1 \mathrm{H}, \mathrm{CH}_{2}\right), 3.98-4.01\left(\mathrm{~m}, 2 \mathrm{H}, \mathrm{CH}_{2}\right)$, $3.23\left(\mathrm{~d}, J 16.4 \mathrm{~Hz}, 1 \mathrm{H}, \mathrm{CH}_{2}\right), 2.82\left(\mathrm{~d}, J 16.4 \mathrm{~Hz}, 1 \mathrm{H}, \mathrm{CH}_{2}\right), 2.17\left(\mathrm{~m}, 1 \mathrm{H}, \mathrm{CH}_{2}\right), 2.13\left(\mathrm{~m}, 1 \mathrm{H}, \mathrm{CH}_{2}\right), 1.97\left(\mathrm{~m}, 1 \mathrm{H}, \mathrm{CH}_{2}\right)$, $1.88\left(\mathrm{~m}, 1 \mathrm{H}, \mathrm{CH}_{2}\right)$. HPLC: CHIRALPAK OJ-H, UV-detector: $210 \mathrm{~nm}$, eluent: $i$-PrOH:hexane 90:10, retentiom time: $9.84 \mathrm{~min}, 18.60 \mathrm{~min} .{ }^{1} \mathrm{H}$ NMR data corresponds to previously reported data. ${ }^{13}$

4,5-Dihydro-3H-spiro[furan-2,3'-isochromane] (16). Results are as shown in Table 2. Isolated as a mixture of spiroketals 15 and 16. ${ }^{1} \mathrm{H}$ NMR $\left(400 \mathrm{MHz}, \mathrm{CDCl}_{3}\right) \delta(\mathrm{ppm})$ 7.13-7.17 (m, 2H, $\left.\mathrm{CH}_{\mathrm{Ar}}\right), 7.07-7.10\left(\mathrm{~m}, 1 \mathrm{H}, \mathrm{CH}_{\mathrm{Ar}}\right), 6.99-$ $7.02\left(\mathrm{~m}, 1 \mathrm{H}, \mathrm{CH}_{\mathrm{Ar}}\right), 4.92\left(\mathrm{~d}, J 14.8 \mathrm{~Hz}, 1 \mathrm{H}, \mathrm{CH}_{2}\right), 4.67\left(\mathrm{~d}, J 14.8 \mathrm{~Hz}, 1 \mathrm{H}, \mathrm{CH}_{2}\right), 3.98-4.01\left(\mathrm{~m}, 2 \mathrm{H}, \mathrm{CH}_{2}\right), 3.23(\mathrm{~d}, J$ $\left.16.4 \mathrm{~Hz}, 1 \mathrm{H}, \mathrm{CH}_{2}\right), 2.82\left(\mathrm{~d}, J 16.4 \mathrm{~Hz}, 1 \mathrm{H}, \mathrm{CH}_{2}\right), 2.17\left(\mathrm{~m}, 1 \mathrm{H}, \mathrm{CH}_{2}\right), 2.13\left(\mathrm{~m}, 1 \mathrm{H}, \mathrm{CH}_{2}\right), 1.97\left(\mathrm{~m}, 1 \mathrm{H}, \mathrm{CH}_{2}\right), 1.88(\mathrm{~m}$, $1 \mathrm{H}, \mathrm{CH}_{2}$ ). HPLC: CHIRALPAK OJ-H, UV-detector: $210 \mathrm{~nm}$, eluent: i-PrOH:hexane 90:10, retention time: 11.05 $\min , 15.34 \mathrm{~min} .{ }^{1} \mathrm{H}$ NMR data corresponds to previously reported data. ${ }^{13}$

(2-(1H-isochromen-3-yl)phenyl)methanol (18). Performed according the general procedure, with the reaction being terminated after $10 \mathrm{~min} .{ }^{1} \mathrm{H} \mathrm{NMR}\left(600 \mathrm{MHz}, \mathrm{CD}_{2} \mathrm{Cl}_{2}\right) \delta(\mathrm{ppm}) 7.56\left(\mathrm{dd}, J 7.7,0.9 \mathrm{~Hz}, 1 \mathrm{H}, \mathrm{CH}_{\mathrm{Ar}}\right), 7.52$ (apparent d, J $7.6 \mathrm{~Hz}, 1 \mathrm{H}, \mathrm{CH}_{\mathrm{Ar}}$ ), $7.44\left(\mathrm{td}, J 7.7,1.3 \mathrm{HZ}, 1 \mathrm{H}, \mathrm{CH}_{\mathrm{Ar}}\right), 7.37$ (td, J 7.5, $1.1 \mathrm{~Hz}, 1 \mathrm{H}, \mathrm{CH}_{\mathrm{Ar}}$ ), 7.31 (apparent t, J 7.6 Hz, 1H, $\left.\mathrm{CH}_{\mathrm{Ar}}\right), 7.24\left(\mathrm{td}, J 7.6,1.0 \mathrm{~Hz}, 1 \mathrm{H}, \mathrm{CH}_{\mathrm{Ar}}\right), 7.13-7.15\left(\mathrm{~m}, 2 \mathrm{H}, \mathrm{CH}_{\mathrm{Ar}}\right), 6.23(\mathrm{~s}, 1 \mathrm{H}, \mathrm{C}=\mathrm{CH})$, $5.29\left(\mathrm{~s}, 2 \mathrm{H}, \mathrm{CH}_{2}\right), 4.75\left(\mathrm{~d}, J 6.6 \mathrm{~Hz}, 2 \mathrm{H}, \mathrm{CH}_{2} \mathrm{OH}\right), 2.40(\mathrm{t}, J 6.6 \mathrm{~Hz}, 1 \mathrm{H}, \mathrm{OH}) .{ }^{13} \mathrm{C} \mathrm{NMR}\left(150 \mathrm{MHz}, \mathrm{CD}_{2} \mathrm{Cl}_{2}\right) \delta(\mathrm{ppm})$ $155.5(\mathrm{C}=\mathrm{C}), 139.8\left(\mathrm{C}_{\mathrm{Ar}}\right), 134.4\left(\mathrm{C}_{\mathrm{Ar}}\right), 131.6\left(\mathrm{C}_{\mathrm{Ar}}\right), 129.5\left(\mathrm{CH}_{\mathrm{Ar}}\right), 129.3\left(\mathrm{CH}_{\mathrm{Ar}}\right), 128.9\left(\mathrm{CH}_{\mathrm{Ar}}\right), 128.3\left(\mathrm{CH}_{\mathrm{Ar}}\right), 127.7$ $\left(\mathrm{CH}_{\mathrm{Ar}}\right), 127.6\left(\mathrm{C}_{\mathrm{Ar}}\right), 126.8\left(\mathrm{CH}_{\mathrm{Ar}}\right), 123.9\left(\mathrm{C}_{\mathrm{Ar}}\right), 123.5\left(\mathrm{CH}_{\mathrm{Ar}}\right), 105.2(\mathrm{C}=\mathrm{CH}), 68.8\left(\mathrm{CH}_{2}\right), 64.0\left(\mathrm{CH}_{2} \mathrm{OH}\right)$.

\section{Acknowledgements}

We gratefully acknowledge Norwegian University of Science and Technology for a PhD studentship for Helgi Freyr Jónsson. This work was partly supported by the Research Council of Norway through the Norwegian NMR Platform, NNP (226244/F50).

\section{Supplementary Material}

${ }^{1} \mathrm{H}$ and ${ }^{13} \mathrm{C}$ NMR spectra of novel compounds $11 \mathrm{c}, \mathrm{e}, 18$ and ${ }^{1} \mathrm{H}$ NMR spectra of known compounds 6, 7, 9, 11a,b,d, 13-16 and 18, as well as chiral HPLC chromatograms, can be found in the Supplementary Material file. 


\section{References}

1. Ishihara, H.; Martin, B. L.; Brautigan, D. L.; Karaki, H.; Ozaki, H.; Kato, Y.; Fusetani, N.; Watabe, S.; Hashimoto, K.; Uemura, D.; Hartshorne, D. J. Biochem Biophys Res Commun. 1989, 159, 871-877. https://doi.org/10.1016/0006-291X(89)92189-X

2. Tachibana, K.; Scheuer, P. J.; Tsukitani, Y.; Kikuchi, H.; Van Engen, D.; Clardy, J.; Gopichand, Y.; Schmitz, F. J. J Am Chem Soc. 1981, 103, 2469-2471.

https://doi.org/10.1021/ja00399a082

3. Pettit, G. R.; Chicacz, Z. A.; Gao, F.; Herald, C. L.; Boyd, M. R.; Schmidt, J. M.; Hooper, J. N. A. J Org Chem. 1993, 58, 1302-1304.

https://doi.org/10.1021/jo00058a004

4. Fortner, K. C.; Kato, D.; Tanaka, Y.; Shair, M. D. J Am Chem Soc. 2010, 132, 275-280. https://doi.org/10.1021/ja906996c

5. Smith III, A. B.; Doughty, V. A.; Lin, Q.; Zhuang, L.; McBriar, M. D.; Boldi, A. M.; Moser, W. H.; Murase, N.; Nakayama, K.; Sobukawa, M. Angew Chemie Int Ed. 2001, 40, 191-195. https://doi.org/10.1002/1521-3773(20010105)40:1<191::AID-ANIE191>3.0.CO;2-C

6. White, J. D.; Hanselmann, R.; Jackson, R. W.; Porter, W. J.; Ohba, Y.; Tiller, T.; Wang, S. J Org Chem. 2001, 66, 5217-5231

https://doi.org/10.1021/jo0104429

7. Gillard, R. M.; Brimble, M. A. Org Biomol Chem. 2019, 17, 8272-8307. https://doi.org/10.1039/C90B01598A

8. Evans, D. A.; Coleman, P. J.; Dias, L. C. Angew Chemie Int Ed English. 1997, 36, 2738-2741. https://doi.org/10.1002/anie.199727381

9. Matsumoto, K.; Kozmin, S. A. Adv Synth Catal. 2008, 350, 557-560. https://doi.org/10.1002/adsc.200700537

10. Evans, D. A.; Kaldor, S. W.; Jones, T. K.; Clardy, J.; Stout, T. J. J Am Chem Soc. 1990, 112, 7001-7031. https://doi.org/10.1021/ja00175a038

11. Messerle, B. A.; Vuong, K. Q. Pure Appl Chem. 2006, 78. https://doi.org/10.1351/pac200678020385

12. Liu, B.; De Brabander, J. K. Org Lett. 2006, 8, 4907-4910. https://doi.org/10.1021/ol0619819

13. Messerle, B. A.; Vuong, K. Q. Organometallics. 2007, 26, 3031-3040. https://doi.org/10.1021/om061106r

14. lio, K.; Sachimori, S.; Watanabe, T.; Fuwa, H. Org Lett. 2018, 20, 7851-7855. https://doi.org/10.1021/acs.orglett.8b03368

15. Trost, B. M.; Weiss, A. H. Angew Chemie Int Ed. 2007, 46, 7664-7666 https://doi.org/10.1002/anie.200702637

16. Zi, W.; Dean Toste, F. Chem Soc Rev. 2016, 45, 4567-4589. https://doi.org/10.1039/C5CS00929D

17. Quach, R.; Furkert, D. P.; Brimble, M. A. Org Biomol Chem. 2017, 15, 3098-3104. https://doi.org/10.1039/C7OB00496F

18. Fang, C.; Pang, Y.; Forsyth, C. J. Org Lett. 2010, 12, 4528-4531. https://doi.org/10.1021/ol101833h

19. Reddy, D. V.; Sabitha, G.; Rao, T. P.; Yadav, J. S. Org Lett. 2016, 18, 4202-4205. 
https://doi.org/10.1021/acs.orglett.6b01849

20. Li, Y.; Zhou, F.; Forsyth, C. J. Angew Chemie Int Ed. 2007, 46, 279-282.

https://doi.org/10.1002/anie.200601963

21. Tlais, S. F.; Dudley, G. B. Beilstein J Org Chem. 2011, 7, 570-577.

https://doi.org/10.3762/bjoc.7.66

22. Aponick, A.; Li, C.-Y.; Palmes, J. A. Org Lett. 2009, 11, 121-124.

https://doi.org/10.1021/ol802491m

23. Blanco Jaimes, M. C.; Böhling, C. R. N.; Serrano-Becerra, J. M.; Hashmi, A. S. K. Angew Chemie Int Ed. 2013, 52, 7963-7966.

https://doi.org/10.1002/anie.201210351

24. Nair, A. G.; McBurney, R. T.; Gatus, M. R. D.; Binding, S. C.; Messerle, B. A. Inorg Chem. 2017, 56, 1206712075.

https://doi.org/10.1021/acs.inorgchem.7b02161

25. Deslongchamps, P. Pergamon Press; 1983.

https://doi.org/10.1002/ange.19840960838

26. Sun, Z.; Winschel, G. A.; Borovika, A.; Nagorny, P. J Am Chem Soc. 2012, 134, 8074-8077.

https://doi.org/10.1021/ja302704m

27. Wilsdorf, M.; Reissig, H.-U. Angew Chemie Int Ed. 2012, 51, 9486-9488.

https://doi.org/10.1002/anie.201203847

28. Franz, A. K.; Hanhan, N. V; Ball-Jones, N. R. ACS Catal. 2013, 3, 540-553.

https://doi.org/10.1021/cs300801y

29. Wang, X.; Han, Z.; Wang, Z.; Ding, K. Angew Chemie Int Ed. 2012, 51, 936-940.

https://doi.org/10.1002/anie.201106488

30. Rexit, A. A.; Mailikezati, M. Tetrahedron Lett. 2015, 56, 2651-2655.

https://doi.org/10.1016/j.tetlet.2015.03.007

31. Quach, R.; Furkert, D. P.; Brimble, M. A. Tetrahedron Lett. 2013, 54, 5865-5868.

https://doi.org/10.1016/j.tetlet.2013.08.077

32. Čorić, I., List, B. Nature. 2012, 483, 315-319.

https://doi.org/10.1038/nature10932

33. Reiersølmoen, A. C.; Østrem, E.; Fiksdahl, A. European J Org Chem. 2018, 2018, 3317-3325. https://doi.org/10.1002/ejoc.201800419

34. ReiersøImoen, A. C.; Fiksdahl, A. European J Org Chem. 2020, 19, 2867-2877. https://doi.org/10.1002/ejoc.202000139

35. Reiersølmoen, A. C.; Csókás, D.; Pápai, I.; Fiksdahl, A.; Erdélyi, M. J Am Chem Soc. 2019, 141, 18221-18229. https://doi.org/10.1021/jacs.9b09108

36. Bohan, P. T.; Toste, F. D. J Am Chem Soc. 2017, 139, 11016-11019.

https://doi.org/10.1021/jacs.7b06025

37. Kumar, A.; Singh, C.; Tinnermann, H.; Huynh, H. V. Organometallics. 2020, 39, 172-181. https://doi.org/10.1021/acs.organomet.9b00718

38. Cala, L.; Mendoza, A.; Fañanás, F. J.; Rodríguez, F. Chem Commun. 2013, 49, 2715-2717. https://doi.org/10.1039/c3cc00118k

39. Wu, H.; He, Y.-P.; Gong, L.-Z. Org Lett. 2013, 15, 460-463.

https://doi.org/10.1021/ol303188u

40. Visbal, R.; Herrera, R. P.; Gimeno, M. C. Chem - A Eur J. 2019, 25, 15837-15845. 
https://doi.org/10.1002/chem.201903494

41. Zhang, Y.; Xue, J.; Xin, Z.; Xie, Z.; Li, Y. Synlett. 2008, 2008, 940-944.

https://doi.org/10.1055/s-2008-1042910

42. Ho, J. H. H.; Choy, S. W. S.; Macgregor, S. A.; Messerle, B. A. Organometallics. 2011, 30, 5978-5984. https://doi.org/10.1021/om2007826

43. Nagorny, P.; Sun, Z.; Winschel, G. A. Synlett. 2013, 24, 661-665.

https://doi.org/10.1055/s-0032-1318098

44. Brunner, H.; Amberger, K. J Organomet Chem. 1991, 417, C63-C65.

https://doi.org/10.1016/0022-328X(91)80208-2

45. Cheng, J.; Deming, T. J. Macromolecules. 1999, 32, 4745-4747. https://doi.org/10.1021/ma990241v

46. Brunner, H.; Kagan, H. B.; Kreutzer, G. Tetrahedron: Asymmetry. 2003, 14, 2177-2187. https://doi.org/10.1016/S0957-4166(03)00433-6

47. Padwa, A.; Krumpe, K. E.; Weingarten, M. D. J Org Chem. 1995, 60, 5595-5603. https://doi.org/10.1016/S0957-4166(03)00433-6

48. Menning, S.; Krämer, M.; Coombs, B. A.; Rominger, F.; Beeby, A.; Dreuw, A.; Bunz, U. H. F. J Am Chem Soc. 2013, 135, 2160-2163.

https://doi.org/10.1021/ja400416r 